\title{
Immunoregulation in Sjögren's Syndrome
}

\section{INFLUENCE OF SERUM FACTORS ON T-CELL SUBPOPULATIONS}

\author{
Haralampos M. Moutsopoulos and Anthony S. Fauci, Clinical Immunology \\ Section, Laboratory of Immunology and Microbiology, National Institute of Dental \\ Research, and Clinical Physiology Section, Laboratory of Clinical Investigation, \\ National Institute of Allergy and Infectious Diseases, National Institutes of Health, \\ Bethesda, Maryland 20205
}

A B S T RACT 21 patients with Sjögren's syndrome (sicca syndrome) with either glandular or extraglandular involvement, but without other connective tissue diseases, were studied with regard to immunoregulatory T-cell subpopulations, B-cell function, and suppressor cell capabilities. Patients with isolated glandular disease as well as patients with extraglandular disease had normal absolute numbers of total lymphocytes, T cells, and B cells. However, 9 of 11 patients with extraglandular disease and only 3 of 10 patients with glandular disease had decreased relative proportions of $\mathrm{T}$ cells bearing receptors for the $\mathrm{Fc}$ portion of immunoglobulin (Ig)G ( $\left.\mathrm{T}_{\mathrm{G}}\right)$ which was explained by a factor that blocked the expression of the IgG Fc receptor on $T_{G}$ cells. This blockage was reversible since the factor could be removed by trypsinizing the $T$ cells before $T_{G}$ determination. Serum from patients with abnormal proportions of $T_{G}$ cells, but not serum from patients with normal proportions of $T_{G}$ cells, blocked the expression of the IgG $\mathrm{Fc}_{\mathrm{c}}$ receptor on normal $\mathrm{T}$ cells. The serum factor upon fractionation over Bio-Gel A 1.5 columns as well as over staphylococcal protein A-Sepharose 4B columns was found diffusely within the IgG fraction, and not in the IgM fraction.

Neither patients with glandular nor patients with extraglandular disease manifested increased numbers of in vivo-activated circulating lymphocytes as determined by spontaneous anti-trinitrophenyl (TNP) plaque-forming cells (PFC). However, patients with glandular disease had reduced numbers of pokeweed mitogen-induced anti-sheep erythrocyte PFC ( $P$ $<0.01$ ) as compared with normals and patients with glandular disease. Of note was the fact that despite the modulation of $T_{G}$ subpopulation by the serum factor in patients with extra-glandular disease, these

Received for publication 6 April 1979 and in revised form 13 September 197.9. patients manifested normal concanavalin A-generated suppressor cells of pokeweed mitogen-induced PFC responses in allogeneic co-cultures. This was unlike the suppressor cell defect previously described in this system with systemic lupus erythematosus patients. The discrepancy was attributed both to the fact that the $\mathrm{T}_{\mathrm{G}}$ defect was reversible and to the fact that concanavalin A-generated suppressor cells are not limited to the $T_{G}$ subset. Thus, these studies have demonstrated reversible abnormalities in $\mathrm{T}_{\mathrm{G}}$ cells in patients with extraglandular Sjögren's syndrome which are not associated with suppressor cell defects. The discrepancy between these findings and the immunoregulatory defects demonstrated in systemic lupus erythematosus may explain the difference in severity of the autoimmune expression in these diseases.

\section{INTRODUCTION}

Sjögren's syndrome (sicca syndrome) is a chronic autoimmune disease characterized by T- and B-lymphocyte infiltration of exocrine glands, particularly the lacrimal and salivary glands, resulting in xerostomia and xerophthalmia $(1,2)$. Extraglandular lymphocytic infiltration occurs in one-fourth of patients and usually presents as interstitial pneumonitis, nephritis, myositis, or pseudolymphoma. Rarely, malignant lymphoma occurs, and recently it was shown that sicca syndrome patients are 40 times more prone to develop lymphoma compared with controls (3-7). Sjögren's syndrome can exist as a primary disorder with disease limited to the exocrine glands or with additional extraglandular disease (primary Sjögren's syndrome), or as a component of another connective tissue disease such as rheumatoid arthritis or systemic lupus erythematosus (secondary Sjögren's syndrome) $(1,8)$.

A number of findings suggestive of B-cell hyperreactivity and/or abnormalities of immunoregulation occur in Sjögren's syndrome including hypergammaglobulinemia, nonorgan-specific autoantibodies such as 
rheumatoid factor, and antibodies to extractable nuclear antigen(s) (1, 7-10). In addition, nonrheumatoid factor-circulating IgG immune complexes have been demonstrated in certain patients with this disease (11).

The precise etiology of these abnormalities is unknown. Hyperreactivity of B-cell function may be a primary phenomenon or may be directly or indirectly related to alterations in immunoregulatory mononuclear cells such as thymus-derived (T) cell subpopulations (12). The present study was undertaken to determine if any abnormalities in immunoregulatory $\mathrm{T}$-cell subpopulations as well as B-cell function occur in Sjögren's syndrome. The study was conducted on patients with Sjögren's (either glandular or extraglandular) without other connective tissue diseases. None of the patients were receiving or had received any form of therapy for their disease.

\section{METHODS}

Patient population. 21 patients with Sjögren's syndrome were studied. There were 1 male and 20 females, ranging in age from 34 to $75 \mathrm{yr}$. The diagnosis was based on the presence of the following findings: xerostomia (decreased parotid flow rate, abnormal parotid scan), keratoconjunctivitis sicca demonstrated on slit-lamp examination, and a focal lymphocyte infiltrate on minor salivary gland biopsy. All patients had Sjögren's syndrome alone (primary Sjögren's syndrome) without other connective tissue diseases (1). 10 of the patients had disease limited to exocrine glands, and the remaining 11 had the following extraglandular manifestations: hypergammaglobulinemic purpura, pseudolymphoma, biopsy-proven vasculitis, renal involvement (urine $\mathrm{pH}$ higher than 7 , serum bicarbonate concentration lower than $19 \mathrm{meq} / \mathrm{dl}$, decreased creatinine clearance, and interstitial nephritis on renal biopsy), and interstitial pneumonitis demonstrable on chest roentgenogram and pulmonary function tests (Table I). None of the patients studied were receiving any form of therapy, nor had they ever received any form of therapy for their disease.

The normal control group consisted of 11 age-, sex-, and race-matched individuals.

Cell suspensions. Mononuclear cell suspensions were obtained from heparinized venous blood of patients and normal controls by standard Hypaque-Ficoll gradient centrifugation. Cells were counted in a Coulter counter (model Fn, Coulter Electronics Inc., Hialeah, Fla.), and mononuclear cells were examined in cytocentrifuge preparations stained with WrightGiemsa stain. T cells were identified by the presence of a sur-

\section{TABLE I}

Patients with Sjögren's Syndrome Studied at the National Institutes of Health

\begin{tabular}{|c|c|c|c|c|}
\hline Patient & Sex & Age & $\begin{array}{c}\text { Time since } \\
\text { diagnosis of } \\
\text { Sjögren's syndrome }\end{array}$ & Extraglandular manifestations \\
\hline & & $y r$ & $y r$ & \\
\hline 1 & $\mathbf{F}$ & 51 & 3 & $\begin{array}{l}\text { Hypergammaglobulinemic purpura; renal } \\
\text { involvement }\end{array}$ \\
\hline 2 & $\mathbf{F}$ & 56 & 1 & None \\
\hline 3 & $\mathbf{F}$ & 68 & 1 & Pseudolymphoma \\
\hline 4 & $\mathbf{F}$ & 48 & 1 & None \\
\hline 5 & $\mathbf{F}$ & 45 & 2 & None \\
\hline 6 & $\mathbf{F}$ & 34 & 2 & None \\
\hline 7 & $\mathbf{F}$ & 55 & 6 & Pseudolymphoma; vasculitis \\
\hline 8 & $\mathbf{F}$ & 57 & 3 & Pulmonary involvement \\
\hline 9 & $\mathbf{F}$ & 54 & 2 & Vasculitis \\
\hline 10 & $\mathrm{~F}$ & 48 & 2 & None \\
\hline 11 & $\mathbf{M}$ & 64 & 1 & Vasculitis \\
\hline 12 & $\mathrm{~F}$ & 62 & 7 & Renal involvement \\
\hline 13 & $\mathbf{F}$ & 60 & 8 & Hypergammaglobulinemic purpura \\
\hline 14 & $\mathbf{F}$ & 67 & 1 & None \\
\hline 15 & $\mathbf{F}$ & 62 & 1 & None \\
\hline 16 & $\mathbf{F}$ & 56 & 2 & $\begin{array}{l}\text { Hypergammaglobulinemic purpura; } \\
\text { lymphadenopathy; Waldenstrom's } \\
\text { macroglobulinemia }\end{array}$ \\
\hline 17 & $\mathrm{~F}$ & 63 & 5 & $\begin{array}{l}\text { Hypergammaglobulinemic purpura; chronic } \\
\text { persistent hepatitis; interstitial } \\
\text { pneumonitis }\end{array}$ \\
\hline 18 & F & 60 & 1 & None \\
\hline 19 & $\mathbf{F}$ & 36 & $1 \frac{1}{2}$ & None \\
\hline 20 & $\mathbf{F}$ & 44 & 3 & None \\
\hline 21 & $\mathbf{F}$ & 75 & 1 & Hypergammaglobulinemic purpura \\
\hline
\end{tabular}


face receptor for sheep erythrocytes $(\mathrm{E}),{ }^{1}$ and bone marrowderived (B) cells were identified by the presence of surface immunoglobulin (sIg) determined by a fluoresceinated $F(a b)_{2}$ goat anti-human Ig reagent as previously described (13).

Fractionation of mononuclear cell suspensions. $\mathrm{T}$ cellenriched suspensions were obtained by E-rosetting of lymphocytes with sheep erythrocytes (SRBC) followed by centrifugation of rosetted cells over Hypaque-Ficoll gradients as previously described in detail (14). E-rosetted cells (T cellenriched) separated into the pellet, leaving nonrosetted cells ( $\mathrm{T}$ cell-depleted) at the interface. $\mathrm{T}$ cell-enriched suspensions contained greater than $98 \% \mathrm{~T}$ cells, and T cell-depleted suspensions contained less than $1 \% \mathrm{~T}$ cells. Greater than $90 \%$ of the cells were recovered after the fractionation procedure.

Identification of T-cell subpopulations. T-cell subpopulations were determined as previously described in detail (15, 16). Briefly, to identify $T$ cells bearing receptors for the $F c$ portion of $\operatorname{IgG}\left(\mathrm{T}_{\mathrm{G}}\right), 0.1 \mathrm{ml}$ of purified $\mathrm{T}$ cells at a concentration of $10 \times 10^{6}$ cells $/ \mathrm{ml}$ was mixed with $0.1 \mathrm{ml}$ of a $2 \%$ suspension of bovine $E$ coated with highly purified rabbit antibovine $E$ IgG antibody (7S EA). This mixture was spun into a pellet and incubated at $37^{\circ} \mathrm{C}$ for $30 \mathrm{~min}$. To identify $\mathrm{T}$ cells bearing receptors for the Fc portion of IgM ( $\mathrm{T}_{\mathrm{M}}$ cells), purified $\mathrm{T}$ cells were incubated overnight at a concentration of $10^{6} \mathrm{cells} / \mathrm{ml}$ in TC 199 media (Grand Island Biological Co., Grand Island, N. Y.) and $20 \%$ fetal calf serum. After overnight incubation, the T cells were suspended in TC 199 at $3 \times 10^{6} \mathrm{cells} / \mathrm{ml}$, and 0.1 $\mathrm{ml}$ was added to $0.1 \mathrm{ml}$ of a $0.5 \%$ suspension of bovine $\mathrm{E}$ coated with purified rabbit antibovine E IgM (19S EA). The Tcell-19S EA mixture was spun into a pellet and incubated on ice for $45 \mathrm{~min}$.

After incubation of T cells with either IgG or IgM EA reagents, the buttons were gently resuspended, and the percentage of rosette-positive cells was counted under phase-contrast microscopy. On every sample, 200 cells were counted by the same observer throughout the study. Lymphocytes binding three or more $\mathrm{E}$ were classified as rosettes. The percentages of $T$ cells bearing $F c$ receptors for $\operatorname{IgG}\left(T_{G}\right)$ or $\operatorname{IgM}\left(T_{M}\right)$ were thus determined. The percentage of T-cells having neither receptor $\left(\mathrm{T}_{\text {non-Gi, non-M}}\right.$, or $\left.\mathrm{T}_{\text {null }}\right)$ was determined by subtracting the sum of the percentage of $T_{G}$ cells and $T_{M}$ cells from 100 .

Trypsin treatment of $T$ cells. To determine if a factor which was trypsin sensitive might be influencing the expression of the Fc receptor for IgG in the patients studied, in certain experiments purified $T$ cells from normal subjects and patients were examined for the proportion of $T_{G}$ cells both before and after treatment with trypsin. The trypsin treatment protocol consisted of determining the proportion of $T_{G}$ in separate aliquots of purified $\mathrm{T}$ cells which had been incubated with either RPMI-1640 media (Microbiological Associates, Walkersville, Md.) or trypsin (Sigma Chemical Co., St. Louis, Mo.) $2 \mathrm{mg} / \mathrm{ml}$ for $30 \mathrm{~min}$ at $37^{\circ} \mathrm{C}$ followed by three washes in RPMI-1640.

Preincubation of $T$ cells with whole serum and serum fractions. To determine the effect of whole serum from Sjögren's syndrome patients on the expression of the Fc receptor for IgG found on normal T cells, the following experiments were performed. A determination of the proportion of $T_{G}$ cells was made on aliquots of $\mathrm{T}$-cell suspensions from normal indi-

${ }^{1}$ Abbreviations used in this paper: A, antibody; Con A, concanavalin A; E, erythrocyte; PFC, plaque-forming cells; PHA, phytohemagglutinin; PWM, pokeweed mitogen; sIg, surface immunoglobulin; SLE, systemic lupus erythematosus; SRBC, sheep erythrocyte; $T_{G}, T$ cells bearing receptors for the $F_{c}$ portion of IgG; $T_{M}, T$ cells bearing receptors for the $F c$ portion of Ig.M. viduals. Separate aliquots of T cells were then preincubated for $45 \mathrm{~min}$ at $37^{\circ} \mathrm{C}$ with 1:10 dilution of heat-inactivated sera from normal individuals or from patients with Sjögren's syndrome. Cells were then washed twice and $T_{G}$ determinations were repeated.

For the experiments using serum fractions, the following procedures were carried out: sera from three patients and one normal individual were heat-inactivated at $56^{\circ} \mathrm{C}$ for $30 \mathrm{~min}$ and were fractionated on a Bio-Gel A 1.5 column $(1 \times 90 \mathrm{~cm})$ as previously described (17). $1-\mathrm{ml}$ fractions were collected from the column and localization of the 19S (IgM) and 7S (IgG) peaks was performed by radial immunodiffusion (Hyland Diagnostics Div., Travenol Laboratories, Inc., Costa Mesa, Calif.). The fractions were then dialyzed against phosphatebuffered saline ( $\mathrm{pH} 7.4$ ), concentrated to the original volume and airfused before use (Airfuse; Beckman Instruments, Inc., Fullerton, Calif.).

In a separate series of experiments the serum fractions from a patient with extraglandular Sjögren's syndrome and a low proportion of $\mathrm{T}_{\mathrm{G}}(2 \%)$, serum from a patient with glandular Sjögren's syndrome and a normal proportion of $\mathrm{T}_{\mathrm{G}}(12 \%)$, and serum from a normal individual $\left(15 \% \mathrm{~T}_{\mathrm{G}}\right)$ were fractionated by multiple passages over a column of Sepharose $4 \mathrm{~B}$ with bound staphylococcal protein A (Pharmacia Fine Chemicals, Div. Pharmacia Inc., Piscataway, N. J.) according to previously described methods (18). Pooled serum fractions either devoid of detectable IgG or enriched in IgG were obtained by this fractionation procedure. Preincubation of $\mathrm{T}$ cells with the serum fractions was carried out in the same manner as described above for the unfractionated sera.

Blastogenic responses. Lymphocyte blastogenic responses to stimulation with the mitogens phytohemagglutinin (PHA) (concentration range from 0.5 to $10 \mu \mathrm{g} / \mathrm{ml}$ of culture), concanavalin A (Con A) (10-250 $\mu \mathrm{g} / \mathrm{ml}$ of culture), and pokeweed mitogen (PWM) (1:20 through 1:1,000 dilution of stock solution per milliliter of culture) were determined by the incorporation of tritiated thymidine in microcultures as previously described in detail (13). Cultures stimulated with PHA and Con $\mathrm{A}$ were incubated for $3 \mathrm{~d}$, and cultures stimulated with PWM were incubated for $5 \mathrm{~d}$.

Determination of plaque-forming cell (PFC) responses. Determination of $\mathrm{B}$ cells spontaneously producing Ig was made by immediately assaying freshly drawn Hypaque-Ficollseparated mononuclear cells in a hemolysis-in-gel PFC assay as previously described (19), with the modification that the SRBC targets were haptenated with the trinitrophenyl hapten (20).

The polyclonally induced PFC responses against SRBC of lymphocytes from Sjögren's syndrome patients and normal subjects after 6-7 d of culture with PWM were also determined as previously described (19). Briefly, cells were cultured in RPMI-1640 media (Grand Island Biological Co.) containing $0.3 \%$ trypticase soy broth, $2 \mathrm{mM} \mathrm{L}$-glutamine, $100 \mathrm{U} / \mathrm{ml}$ of penicillin, $100 \mu \mathrm{g} / \mathrm{ml}$ of streptomycin sulfate, and supplemented with $10 \%$ pooled human A serum absorbed twice with SRBC. Cultures were performed in $12 \times 75-\mathrm{mm}$ plastic tubes (Falcon Labware, Div. of Becton, Dickinson \& Co., Oxnard, Calif.) at a density of $2 \times 10^{6}$ cells in $1 \mathrm{ml}$, on a rocker platform ( 7 cycles $/ \mathrm{min}$ ) for $6-7 \mathrm{~d}$ at $37^{\circ} \mathrm{C}$ in $5 \% \mathrm{CO}_{2}$ in air at $100 \%$ humidity. Cultures were stimulated either with PWM in a wide concentration range (1:20 through $1: 10,000$ final dilution) or media alone as control (background PFC).

In allogeneic co-cultures of cell suspensions from a Sjögren's syndrome patient and a normal individual, $1 \times 10^{6}$ cells of one suspension were co-cultured with $1 \times 10^{6}$ cells of another suspension to keep the cell density constant at $2 \times 10^{6}$ cells in $1 \mathrm{ml}$.

At the end of the culture period (6-7 d), cells were harvested and assayed for direct PFC against SRBC by an ultrathin layer 
hemolysis-in-gel technique as previously described in detail (19). Data are expressed as PFC per $10^{6}$ cells.

Con A-generated suppressor cells. Suppressor cells were activated by incubation with Con A (grade IV, Sigma Chemical Co.) as previously described in detail (21). Briefly, lymphocytes at a density of $5 \times 10^{6}$ cells $/ 2 \mathrm{ml}$ of RPMI-1640 were incubated in flat-bottomed Linbro plates (Linbro Chemical Co., Hamden, Conn.) either with $10 \mu \mathrm{g} / \mathrm{ml}$ Con $\mathrm{A}$, a dose previously shown to be optimal for generating suppressor cells (21), or with no Con A as a control. At $48 \mathrm{~h}$, cells were harvested, washed three times with $0.2 \mathrm{M} \alpha$-methyl mannoside (Calbiochem-Behring Corp., American Hoechst Corp., San Diego, Calif.), and once with RPMI-1640 media. Control cells were not exposed to Con A on initiation of culture, but were cultured alone for $48 \mathrm{~h}$ and washed with $\alpha$-methyl mannoside in the same manner as the cells that were cultured with Con A. Con A-activated or control cells (unstimulated) from normals or patients were co-cultured with freshly drawn allogeneic normal lymphocytes in the presence of PWM for an additional 6-7 d to determine the effect of Con A-activated suppressor cells on the PWM-induced PFC response against SRBC.

\section{RESULTS}

Lymphocyte subpopulations. The absolute numbers of lymphocytes, total T cells, and B cells in normal individuals and patients with either glandular Sjögren's syndrome or extraglandular Sjögren's syndrome are shown in Fig. 1. There were no significant differences between normal individuals and patients with glandular Sjögren's syndrome in absolute numbers of lymphocytes, T cells, or B cells. Patients with extraglandular Sjögren's syndrome had slightly lower numbers of total lymphocytes and $\mathrm{T}$ cells than normal individuals, but these differences were not significant. When relative proportions of T-cell subsets were determined, again there were no significant differences among normals, glandular, and extraglandular Sjögren's syndrome patients (Fig. 2). However, when proportions of $T_{G}$ cells (by 7S EA-rosetting) were examined in individual patients with glandular and extraglandular Sjögren's syndrome, an obvious difference was noted (Fig. 3). 7 of 10

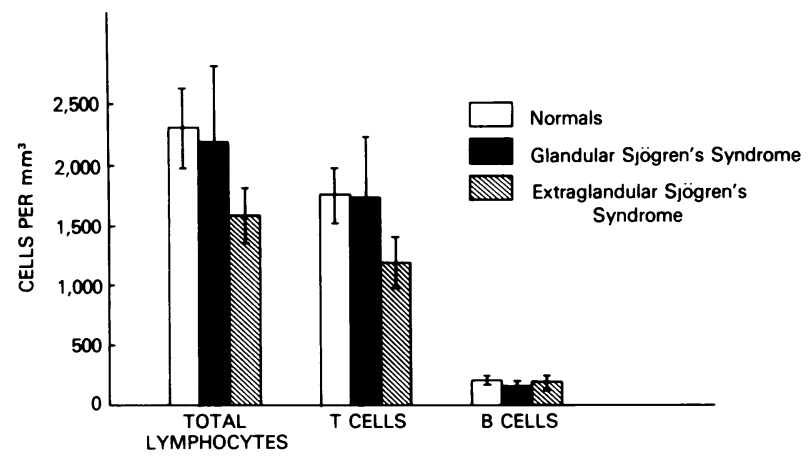

FIGURE 1 Absolute numbers of lymphocytes, T cells, and B cells in normals, patients with glandular Sjögren's syndrome, and patients with extraglandular Sjögren's syndrome. There were no significant differences in lymphocytes, T, or B cells among the three groups.

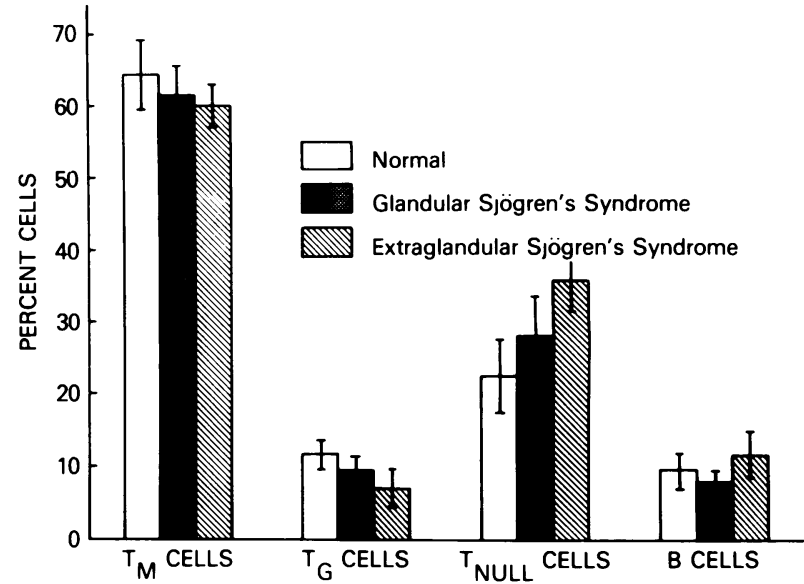

FIGURE 2 Proportions of T-cell subsets in normals, patients with glandular Sjögren's syndrome, and patients with extraglandular Sjögren's syndrome. There were no significant different in T-cell subsets or B cells among the three groups $(P>0.2)$.

patients with glandular Sjögren's syndrome had proportions of $T_{G}$ cells which were within the range of concomitantly determined normal values. On the contrary, 9 of 11 patients with extraglandular Sjögren's syndrome had proportions of $\mathrm{T}_{\mathrm{G}}$ cells which were decreased below the normal range. Incubation of the $\mathrm{T}$ cells for

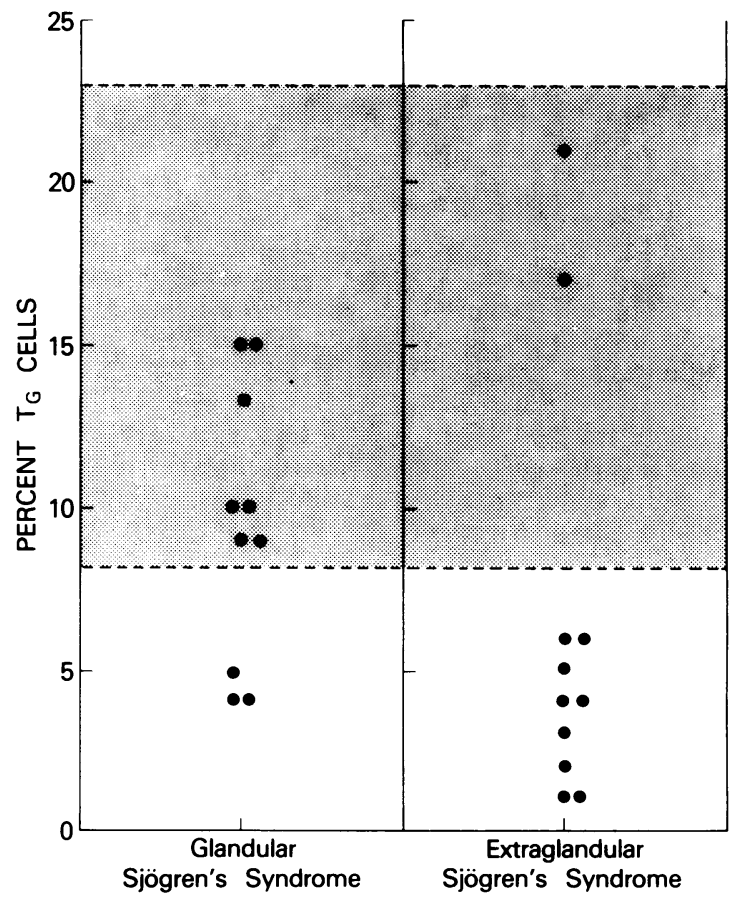

Figure 3 Proportion of $T_{G}$ cells in patients with glandular and extraglandular Sjögren's syndrome. Each dot represents a patient and shaded area signifies the normal range of concomitantly determined $T_{G}$ proportions among normal individuals. 
$1 \mathrm{~h}$ at $37^{\circ} \mathrm{C}$ followed by washing in RPMl- 1640 failed to result in normalization of the expression of $\operatorname{IgG~} \mathrm{Fc}$ receptors in those cell suspensions with low levels of detectable $T_{G}$ cells. Determinations were repeated at least once and sometimes twice over a period of 1-4 mo in seven patients (five patients with low $\mathrm{T}_{\mathrm{G}}$ and two with normal $\mathrm{T}_{\mathrm{G}}$ ). Values were within $2 \%$ rosettes on these repeat determinations.

Effect of trypsin treatment of T cells upon expression of IgG Fc receptor. The effect of trypsin treatment of T cells from extraglandular Sjögren's syndrome patients who manifested low proportions of $T_{G}$ cells is shown in Table II. In four of the five individuals tested, trypsin treatment resulted in an increase in detectable IgG $\mathrm{Fc}_{\mathrm{c}}$ receptor-bearing $\mathrm{T}$ cells to near normal or normal levels suggesting that a trypsin-sensitive factor was reversibly blocking the detection of the IgG Fc receptor on a proportion of these cells. In addition, trypsin treatment of $\mathrm{T}$ cells from normal individuals and Sjögren's syndrome patients with normal proportions of $T_{G}$ cells did not affect the proportion of cells with detectable IgG Fc receptors. Trypsin treatment of the T cells from one patient with glandular Sjögren's syndrome and low $T_{G}$ resulted in normalization of the proportion of $\mathrm{T}_{\mathrm{G}}$.

Effect of sera from patients with Sjögren's syndrome on the expression of $\operatorname{IgG} F \mathrm{~F}$ receptors on normal $T$ cells. The effect of preincubation of normal $\mathrm{T}$ cells with sera from normal individuals, from glandular

TABLE II

Effect of Trypsinization of T Cells on the Expression of the IgG Fc Receptor in Sjögren's Syndrome and in Normal Individuals

\begin{tabular}{lcc}
\hline & \multicolumn{2}{c}{ Percent $\mathrm{T}_{\mathrm{G}}$} \\
\cline { 2 - 3 } \multicolumn{1}{c}{ Subject } & $\begin{array}{c}\text { Before } \\
\text { trypsinization }\end{array}$ & $\begin{array}{c}\text { After } \\
\text { trypsinization }\end{array}$ \\
\hline $\begin{array}{l}\text { Extraglandular Sjögren's } \\
\text { syndrome }\end{array}$ & & \\
A & 4 & 19 \\
B & 5 & 11 \\
C & 4 & 8 \\
D & 2 & 1 \\
E & 2 & 12 \\
Glandular Sjögren's & & \\
$\quad$ syndrome & & 14 \\
A & 15 & 15 \\
B & 14 & 12 \\
C & 10 & 11 \\
D & 10 & 13 \\
Normals & & 13 \\
A & 12 & 12 \\
B & 11 & 13 \\
C & 15 & \\
D & 11 & \\
\end{tabular}

Sjögren's syndrome patients with normal $\mathrm{T}_{\mathrm{G}}$-cell proportions, and from extraglandular Sjögren's syndrome patients with low $\mathrm{T}_{\mathrm{G}}$-cell proportions is shown in Fig. 4. Preincubation of $\mathrm{T}$ cells with normal sera or sera from patients with glandular Sjögren's syndrome and normal $\mathrm{T}_{\mathrm{G}}$-cell levels had very little effect on the detection of IgG $\mathrm{Fc}$ receptors on these normal $\mathrm{T}$ cells. In contrast, sera from each of six patients tested with extraglandular Sjögren's syndrome who had low $T_{G}$ cell proportions blocked the expression of the IgG $\mathrm{FC}_{\mathrm{C}}$ receptor on normal $\mathrm{T}$ cells.

In additional studies in which normal $\mathrm{T}$ cells were incubated with sera at $27^{\circ} \mathrm{C}$ or $4^{\circ} \mathrm{C}$, sera from normals or patients with glandular Sjögren's syndrome and normal proportions of $\mathrm{T}_{\mathrm{G}}$ still did not block the expression of the IgG $\mathrm{Fc}$ receptor on the normal $\mathrm{T}$ cells. This suggests that low titer-blocking factors which might bind detectably only at lower temperatures were not present in the sera of normal individuals and patients with normal $\mathrm{T}_{\mathrm{G}}$.

Effect of serum fractions. Sera from normal individuals and patients with extraglandular Sjögren's syndrome whose whole serum had blocked the expression of the IgG Fc receptor on normal T cells were fractionated over Bio-gel A 1.5 columns. The Fc receptorblocking activity was found in the fractions containing IgG and in fractions containing IgM. Fig. 5 illustrates a typical fraction curve containing the Fc receptor-blocking activity. None of the fractions from normal serum blocked $\mathrm{Fc}$ receptor expression. The inhibitory fractions illustrated in Fig. 5 upon incubation with normal $\mathrm{T}$ cells decreased the percentage of $\mathrm{Fc}$ receptor expressing cells from $13 \%$ to a range of from 2 to $5 \%$.

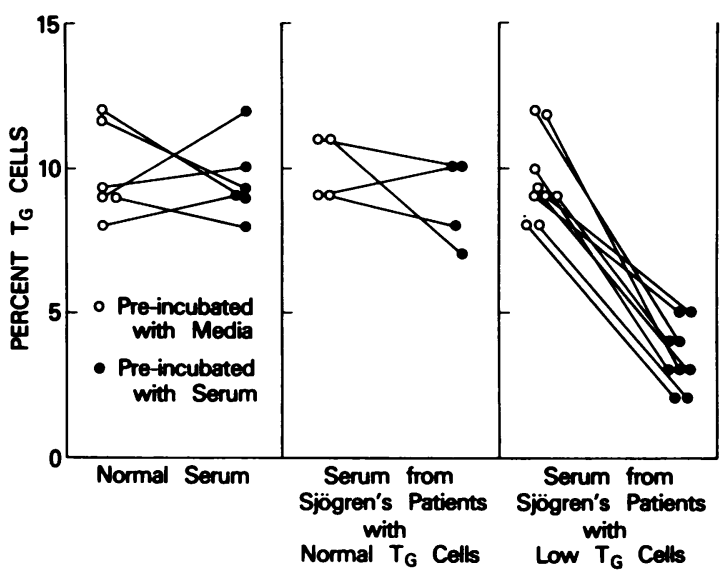

FIGURE 4 Effect of incubation of normal T cells with sera from Sjögren's syndrome patients on the expression of IgG Fc receptor. Serum from six patients with Sjögren's syndrome who had low levels of $T_{G}$ blocked the expression of the IgG Fc receptor on normal $T$ cells. In this figure, sera from three of the six patients with low $T_{G}$ were assayed against two separate normals, thus giving a total of nine determinations (right panel). 


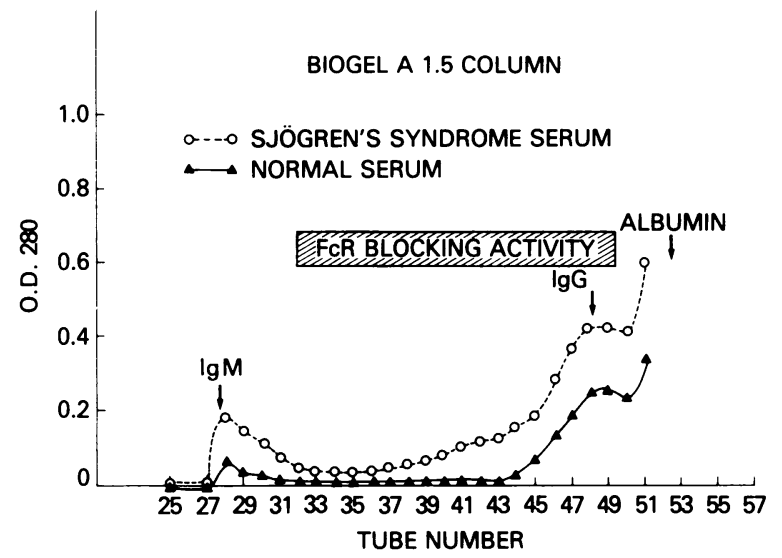

Figure 5 Fractionation of Sjögren's syndrome serum. This figure represents a typical fractionation profile of the serum from a patient with low $T_{G}$ proportion whose whole serum blocked the expression of the IgG $\mathrm{Fc}_{\mathrm{c}}$ receptor on normal $\mathrm{T}$ cells. The blocking activity was diffusely distributed (represented by shaded bar) but excluded the fractions containing Ig.M.

In a separate series of experiments in which various sera were fractionated into IgG-containing and IgGdepleted fractions by passage over columns of staphylococcal protein A bound to Sepharose 4B, only the IgG-containing fraction of the patient with extraglandular Sjögren's syndrome and low $\mathrm{T}_{\mathrm{G}}$ proportion blocked the expression of the IgG Fc receptor on normal T cells (Table III). This finding was reproducible in three separate experiments.

Lymphocyte blastogenic responses. The peak blastogenic responses of lymphocytes from normal individuals and patients with glandular and extraglandular Sjögren's syndrome to stimulation with various mitogens are shown in Fig. 6. Although there appeared to be a trend towards slightly decreased responses to all mitogens tested in patients with glandular Sjögren's syndrome and even more so in patients with extraglandular Sjögren's syndrome, these decreases were not statistically significant $(P>0.2$, Student's $t$ test). When suboptimal concentrations of mitogens were used, responses were still not statistically different among the three groups.

PFC responses. There was no difference between normal individuals and any patients with Sjögren's syndrome in the presence of spontaneously occurring PFC responses against TNP-coated sheep cells. There were virtually no responses $\left(0-1 \mathrm{PFC} / 10^{6}\right.$ cells) in any of the groups studied.

The PWM-induced PFC responses after 6-7 d in culture of lymphocytes from normal individuals and patients with Sjögren's syndrome are shown in Fig. 7. Patients with glandular Sjögren's syndrome gave PFC responses which were low but which overlapped those of normals. However, PFC responses of patients with
TABLE III

Effect of Serum and Serum Fractions on Expression of Fc Receptor on Normal T Cells*

\begin{tabular}{lc}
\hline \multicolumn{1}{c}{ Source of serum } & $\begin{array}{c}\text { Percentage of Fc receptor } \\
\text { expression on normal T cells }\end{array}$ \\
\hline $\begin{array}{l}\text { Extraglandular Sjögren's syndrome } \\
\text { Media }\end{array}$ & 19 \\
Whole serum & 8 \\
IgG-enriched fraction & 9 \\
IgG-depleted fraction & 20 \\
Glandular Sjögren's syndrome & 15 \\
Media & 15 \\
Whole serum & 17 \\
IgG-enriched fraction & 15 \\
IgG-depleted fraction & 15 \\
Normal & 16 \\
Media & 16 \\
Whole serum & 14 \\
IgG-enriched fraction & \\
IgG-depleted fraction &
\end{tabular}

* Serum fractions were obtained by passage over columns of staphylococcal protein A bound to Sepharose 4B (Methods). $\ddagger$ Normal $T$ cells were preincubated with either media, whole serum, or serum fractions before determination of the proportion of $\mathrm{T}_{\mathrm{G}}$ (Methods).

extraglandular Sjögren's syndrome were markedly decreased below normal $(P<0.001)$.

The low PFC responses of the extraglandular Sjögren's syndrome patients were not due to the exces-

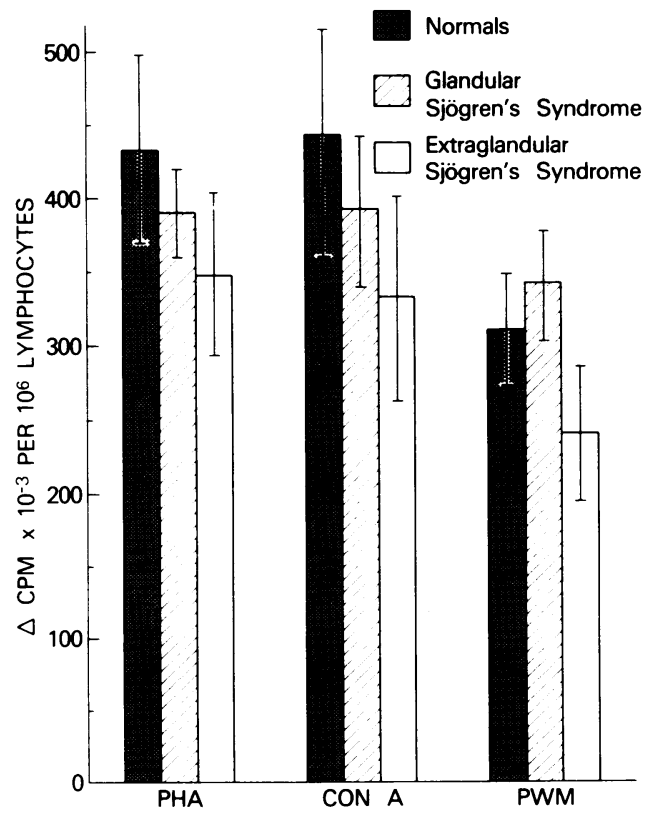

Figure 6 Peak blastogenic responses of normals and Sjögren's syndrome patients to mitogenic stimulation. There were no significant differences $(P>0.2)$ among the three groups in blastogenic responses to PHA, Con A, or PWM. 


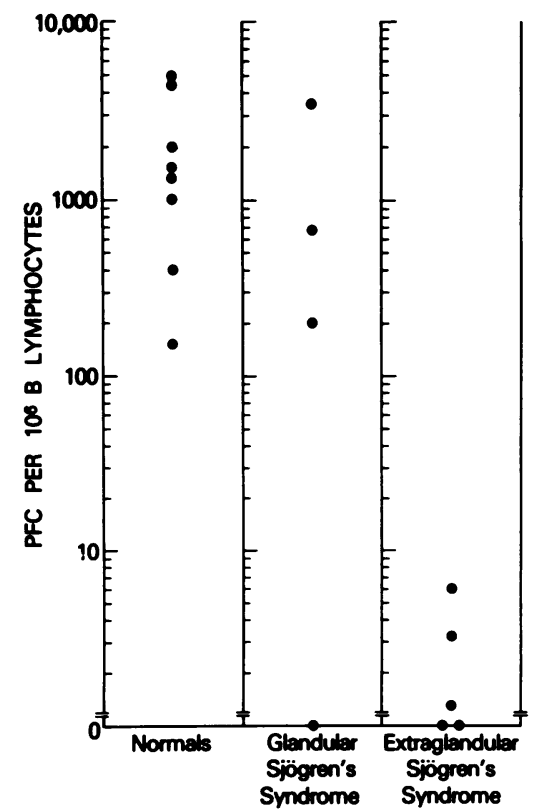

FIGURE 7 PWM-induced anti-SRBC PFC responses in normal individuals and in patients with Sjögren's syndrome. Patients with glandular disease only have PFC responses within the normal range while patients with extraglandular disease have markedly reduced PFC responses. Each dot represents an individual subject and data are plotted on a logarithmic scale as PFC per $10^{6}$ lymphocytes.

sive activity of suppressor cells since co-culture of normal lymphocytes with low responder Sjögren's syndrome lymphocytes, a procedure which detects active suppressor cells (22), did not decrease the expected PFC responses of the normal lymphocytes.

Con A-generated suppressor cells. Lymphocytes from patients with Sjögren's syndrome (either glandular or extraglandular) generated Con A-induced suppressor cells normally. In particular, mononuclear cells from patients, when cultured for $48 \mathrm{~h}$ with Con $\mathrm{A}$, subsequently suppressed the anti-SRBC PFC responses when added to PWM-stimulated allogeneic cocultures. The suppression was no different from that

\section{TABLE IV}

Effect of Con A-Generated Suppressor Cells from Normal Individuals and Patients with Sjögren's Syndrome on the PWM-Induced PFC Responses of Normal Allogeneic Lymphocytes

\begin{tabular}{ll}
\hline \multicolumn{1}{c}{ Subjects } & \multicolumn{1}{c}{$\begin{array}{c}\text { Percentage of } \\
\text { suppression }\end{array}$} \\
\hline Normals $(n=10)^{*}$ & $79( \pm 10.5)$ \\
Glandular Sjögren's syndrome $(n=4)$ & $78( \pm 9)$ \\
Extraglandular Sjögren's syndrome $(n=5)$ & $74( \pm 8)$ \\
\hline
\end{tabular}

* $n$ represents the number of subjects studied.

$\$$ Data are given as the mean $( \pm \mathrm{SEM})$. mediated by Con A-induced suppressor cells from normal individuals $(P>0.2)$ (Table IV).

\section{DISCUSSION}

This study demonstrates that patients with Sjögren's syndrome have an abnormality in the expression of the IgG Fc receptor found on a subpopulation of circulating $T$ cells $\left(T_{G}\right.$ cells). This defect could be normalized by trypsinizing the $T$ cells, after which a normal percentage of these cells expressed IgG Fc receptors. This, together with the finding that sera from patients with low percentages of $T_{G}$ cells when incubated with $T$ cells from normal individuals, blocked the expression of the IgG $\mathrm{Fc}$ receptor on the normal $\mathrm{T}$ cells. The blocking factor was found in the IgG fraction of serum as well as in the fractions between IgG and IgM, but not including IgM. Absorption out of IgG from the serum removed the blocking factor, a finding which suggests that the blocking factor is either an IgG molecule itself or an IgG-containing immune complex. The low percentages of $T_{G}$ as well as the serum factors which blocked the expression of the IgG Fc receptor were found in the patients with extraglandular Sjögren's syndrome and were not found in patients with Sjögren's syndrome limited to the exocrine glands. These findings are of particular interest and potential importance for several reasons. The patients in this study did not have an absolute lymphocytopenia, nor did they have a T lymphocytopenia. Furthermore, although patients with extraglandular Sjögren's syndrome had slightly lower absolute numbers of $T$ cells and all $T$-cell subpopulations $\left(T_{G}, T_{M}\right.$, and $T_{n o n-G}$, $T_{n o n-M}$ ) than normals, these differences were not statistically significant. This agrees with the findings that the expression of receptors of a given T-cell subpopulation were blocked and that the subpopulation itself was not actually depleted. This contrasts with the findings in patients with systemic lupus erythematosus (SLE) about whom several studies have reported a selective depletion of circulating $T_{G}$ cells $(23,24)$ as well as $\mathrm{T}$-cell subsets determined by a number of other methodologies (25-29). This is of particular relevance in light of the fact that in several in vitro systems, SLE has been demonstrated to manifest a deficiency of suppressor cell function (23,30-35). Although the actual suppressor cell in most of these systems has not been conclusively identified, at least in some systems of in vitro $B$-cell function, the $T_{G}$ cell has been demonstrated to be the suppressor cell (16). With regard to the relationship between deficiency of $T_{G}$ cells and lack of suppressor cell function, it should be pointed out that patients with SLE in addition to the deficiency of $T_{G}$ cells $(23,24)$ also manifest a defective ability to generate, after triggering with Con A, suppressor cells of PWMinduced PFC responses (23). In the present study, 
using that same PFC assay of B cell function, patients with Sjögren's syndrome were able to generate Con Asuppressor cells normally. This was true even of those patients with extraglandular disease who had "blocked" $\mathrm{T}_{\mathrm{G}} \mathrm{Fc}$ receptors.

The modulation of $\mathrm{Fc}$ receptors by immune complexes and other factors as well as the effect of such modulation of the $\mathrm{Fc}$ receptor upon the functional capability of the cell is currently a topic of great interest (36-39). With regard to the relationship between $\mathrm{Fc}_{\mathrm{c}}$ receptor modulation and the ability to be subsequently triggered by Con A to generate into a suppressor cell, we have demonstrated that $T_{G}$ cells which are positively selected during purification, i.e., by interaction with 7S EA to form rosettes for fractionation over $\mathrm{Hy}$ paque-Ficoll gradients, are unable to be generated by Con A to express suppressor cell function in the PWMinduced PFC assay (40). It was this finding of inhibition of $\mathrm{T}_{\mathrm{G}}$ function by modulation of $\mathrm{F}_{\mathrm{C}}$ receptors that led to the hypothesis that at least one of the potential mechanisms of the defect in Con A-induced suppressor cell function in SLE was the in vivo modulation of $\mathrm{T}_{\mathrm{G}}$ by circulating immune complexes (23). This however, could not be the entire explanation of the defect in Con Ainduced suppressor cell function in SLE, since we (40) and others (41) have demonstrated that the Con Ainduced suppressor cell of human B-cell function can be found in multiple subpopulations of $\mathrm{T}$ cells and clearly is not confined to the $T_{G}$ population. It is noteworthy, however, that the deficiency of the number of $\mathrm{T}_{\mathrm{G}}$ cells in SLE is apparently irreversible and cannot be normalized by trypsinizing the $\mathrm{T}$ cells (unpublished observations) $)^{2}$, whereas patients with Sjögren's syndrome who have normal Con A-induced suppressor cell function have a reversible deficiency of $\mathrm{T}_{\mathrm{G}}$. A similar reversible effect of serum factors on $\mathrm{Fc}$ receptor function in Sjögren's syndrome was previously demonstrated in a study which showed that a diffusely distributed serum factor in SLE and polyarteritis nodosa reversibly blocked $\mathrm{Fc}_{\mathrm{c}}$ receptor-mediated antibody-dependent cellular cytotoxicity (42).

Since $\sim 80 \%$ of patients with Sjögren's syndrome have circulating immune complexes (11), the role of immune complexes and particularly the probable differences in the effects of immune complexes upon immunoregulatory lymphocyte subpopulations in Sjögren's syndrome as compared with SLE assumes potential importance in our understanding of the modulation of immunoregulatory mechanisms by different types of circulating immune complexes. The complexity of the situation cannot be minimized, however, since other factors such as antilymphocyte antibody may play a major role in the inhibition, if not elimination of suppressor cell populations in $\operatorname{SLE}(28,29)$.

Another important difference between Sjögren's syn- drome and SLE as demonstrated in the present study is the absence in Sjögren's syndrome of increased numbers of spontaneous antibody-producing cells as measured by the the presence in the circulation of spontaneous IgM anti-TNP PFC. Increased numbers of such "preactivated" B cells have been demonstrated in SLE (43-45). We have previously hypothesized that the preactivation of circulating IgM-producing B cells in SLE was likely due to an in vivo polyclonal triggering (23). This was accompanied by a decrease in ability to be triggered in vitro by a de novo polyclonal stimulus such as PWM and hence a decreased PWM-induced anti-SRBC PFC response (23) as was demonstrated in the present study with patients with the more severe extraglandular disease. This same theory was hypothesized by others for the simultaneous in vivo hyperreactivity of B cells and decreased ability of B cells to be polyclonally triggered in vitro as demonstrated in the NZB/NZW mouse model of SLE (46-48).

Since Sjögren's syndrome is a disease of hyperreactivity of B cells, the in vivo preactivation theory is still a likely explanation. Cells that have been preactivated to the point of appearing as spontaneous IgM-producing PFC might not have been found in the circulation in Sjögren's syndrome because they had already been compartmentalized in other lymphoid organs.

Previous studies have demonstrated a T lymphocytopenia in Sjögren's syndrome $(49,50)$, whereas in this study absolute numbers of T-cell subpopulations in patients with Sjögren's syndrome were found to be within normal limits. It should be pointed out that these patients differ from the Sjögren's syndrome patients in these other studies inasmuch as our patients had Sjögren's syndrome alone without any other concomitant connective tissue diseases such as rheumatoid arthritis or SLE. Also, and perhaps most importantly, none of the patients in the present study were receiving any form of therapy nor had they ever received any form of therapy for their Sjögren's syndrome. In this regard, the profound and selective effects of agents such as corticosteroids on $\mathrm{T}$ cells and $\mathrm{T}$-cell subpopulations has been previously described $(51,52)$.

Thus the present study has demonstrated that certain patients with Sjögren's syndrome, particularly of the extraglandular type without coexisting additional connective tissue diseases, have a deficiency of expression of the $F($ receptor for $I g G$ on a population of their $T$ cells ( $T_{G}$ cells). The defective expression is caused by the reversible blocking by a serum factor. This reversibility of effect may explain the lack of detectable abnormalities of modulation of immunoregulatory lymphocyte subpopulations in Sjögren's syndrome as compared with SLE in which irreversible deficiencies of FC receptor-bearing $\mathrm{T}$ cells are accompanied by profound immunoregulatory abnormalities. 


\section{REFERENCES}

1. Block, K. J., W. W. Buchanan, M. J. Wohl, and J. J. Bunim. 1965. Sjögren's syndrome. A clinical, pathological, and serological study of sixty-two cases. Medicine(Baltimore). 44: 187-231.

2. Cummings, N. A., G. L. Schall, R. Asofsky, L. G. Anderson, and N. Talal. 1971. Sjögren's syndrome. Newer aspects of research, diagnosis and therapy. Ann. Intern. Med. 75: 937-950.

3. Anderson, L. G., and N. Talal. 1972. The spectrum of benign to malignant lymphoproliferation in Sjögren's syndrome. Clin. Exp. Immunol. 10: 199-221.

4. Talal, N., and J. J. Bunim. 1964. The development of malignant lymphoma in the course of Sjögren's syndrome. Am. J. Med. 36: 529-540.

5. Talal, N., L. Sokoloff, and W. F. Barth. 1967. Extrasalivary lymphoid abnormalities in Sjögren's syndrome (reticulum cell sarcoma, "pseudolymphoma", macroglobulinemia). Am. J. Med. 43: 50-65.

6. Bunim, J. J., and N. Talal. 1963. The association of malignant lymphoma with Sjögren's syndrome. Trans. Assoc. Am. Physicians. 76: 45-56.

7. Kassan, S. S., T. L. Thomas, H. M. Moutsopoulos, R. Hoover, R. Kimberly, D. R. Budman, J. Costa, J. L. Decker, and T. M. Chused. 1978. Increased risk of lymphoma in sicca syndrome. Ann. Intern. Med. 89: 888-892.

8. Moutsopoulos, H. M., B. L. Webber, T. P. Vlagopoulos, T. M. Chused, and J. L. Decker. 1979. Differences in the clinical manifestations of sicca syndrome in the presence and absence of rheumatoid arthritis. Am. J. Med. 66: 733.

9. Alspaugh, M. A., N. Talal, and E. M. Tan. 1976. Differentiation and characterization of autoantibodies and the antigens in Sjögren's syndrome. Arthritis Rheum. 19: 216222.

10. Akizuki, M., J. J. Boehm-Truitt, S. S. Kassan, A. D. Steinberg, and T. M. Chused. 1977. Purification of an acidic nuclear protein antigen and demonstration of its antibodies in subsets of patients with sicca syndrome. J. Immunol. 119: 932-938.

11. Lawley, T., H. M. Moutsopoulos, S. I. Katz, A. N. Theofilopoulos, T. M. Chused, and M. M. Frank. 1979. Demonstration of circulating immune Complexes in Sjögren's syndrome. J. Immunol. 123: 1382.

12. Talal, N. 1976. Disordered immunologic regulation and autoimmunity. Transplant. Rev. 31: 240-263.

13. Fauci, A. S. 1975. Human bone marrow lymphocytes I. Distribution of lymphocyte subpopulations in the bone marrow of normal individuals. J. Clin. Invest. 56: 98-110.

14. Fauci, A. S., K. R. K. Pratt, and G. Whalen. 1976 Activation of human B lymphocytes II. Cellular interactions in the $\mathrm{PFC}$ response of human tonsillar and peripheral blood B lymphocytes to polyclonal activation by pokeweed mitogen. J. Immunol. 117: 2100-2104.

15. Moretta, L. M., M. Ferrarini, M. C. Mingari, A. Moretta, and S. R. Webb. 1976. Subpopulations of human T cells identified by receptors for immunoglobulins and mitogen responsiveness. J. Immunol. 117: 2171-2174.

16. Moretta, L., S. R. Webb, C. E. Grossi, P. M. Lydyard, and M. D. Cooper. 1977. Functional analysis of two human Tcell subpopulations: help and suppresson of $\mathrm{B}$ cell responses by $\mathrm{T}$ cells bearing receptors for IgM and IgG. J. Exp. Med. 146: 184-200.

17. Hannon, R., M. Haire, G. B. Wisdom, and D. W. Neill. 1975. The use of indirect immunofluorescence to evaluate the gel filtration method of fractionating human immunoglobulins. J. Immunol. Methods. 8: 29-36.
18. Mackenzie, M. R., N. L. Warner, and G. F. Mitchell. 1978. The binding of murine immunoglobulins to staphylococcal protein A. J. Immunol. 120: 1493-1496.

19. Fauci, A. S., and K. R. Pratt. 1976. Polyclonal activation of bone marrow-derived lymphocytes from human peripheral blood measured by a direct plaque-forming cell assay. Proc. Natl. Acad. Sci. U.S.A. 73: 3676-3679.

20. Rittenberg, M. B., and K. L. Pratt. 1969. Antitrinitrophenyl (TNP) plaque assay. Primary response of Balb/c mice to soluble and particulate immunogen. Proc. Soc. Exp. Biol. Med. 132: 575-580.

21. Haynes, B. F. and A. S. Fauci. 1977. Activation of human B lymphocytes. III. Concanavalin A induced generation of suppressor cells of the plaque-forming cell response of normal human B lymphocytes. J. Immunol. 118: 22812287.

22. Fauci, A. S. 1979. Human B cell function in a polyclonally induced plaque forming cell system. Cell triggering and immunoregulation. Immunol. Rev. 45: 93.

23. Fauci, A. S., A. D. Steinberg, B. F. Haynes, and G. Whalen. 1978. Immunoregulatory aberrations in systemic lupus erythematosus. J. Immunol. 121: 1473-1479.

24. Alarćon-Segovia, D., and A. Ruiz-Argüelles. 1978. Decreased circulating thymus-derived cells with receptors for the Fc portion of immunoglobulin $G$ in systemic lupus erthematosus. J. Clin. Invest. 62: 1390-1394.

25. Glinski, W., M. E. Gershwin, and A. D. Steinberg. 1976. Fractionation of cells on a discontinuous ficoll gradient. Study of subpopulations of human T cells using anti-T cell antibodies from patients with systemic lupus erythematosus. J. Clin. Invest. 57: 604-614.

26. Glinski, W., M. E. Gershwin, D. R. Budman, and A. D. Steinberg. 1976. Study of lymphocyte subpopulations in normal humans and patients with systemic lupus erythematosus by fractionation of peripheral blood lymphocytes on a discontinuous Ficoll gradient. Clin. Exp. Immunol. 26: 228-238.

27. Steinberg, A. D., L. W. Klassen, D. R. Budman, and G. W. Williams. 1979. Immunofluorescence studies of anti-T cell antibodies and $\mathrm{T}$ cells in systemic lupus erythematosus. Arthritis Rheum. 22: 114-122.

28. Koike, T., S. Kobayashi, T. Yoshiki, T. Itoh, and T. Shirai. 1979. Differential sensitivity of functional subsets of $T$ cells to the cytotoxicity of natural T-lymphocytotoxic autoantibody of systemic lupus erythematosus. Arthritis Rheum. 22: 123-129.

29. Twomey, J. J., A. H. Laughter, and A. D. Steinberg. 1978. A serum inhibitor of immune regulation in patients with systemic lupus erythematosus. J. Clin. Invest. 61: 713715 .

30. Abdou, N. I., A. Sagawa, E. Pascual, J. Herbert and S. Sadeghee. 1976. Suppressor T-cell abnormality in idiopathic systemic lupus erythematosus. Clin. Immunol. Immunopathol. 6: 192-199.

31. Horowitz, S., W. Borcherding, A. V. Moorthy, R. Chesney, H. Schulte-Wissermann, R. Hong, and A. Goldstein. 1977. Induction of suppressor $\mathrm{T}$ cells in systemic lupus erythematosus by thymosin and cultured thymic epithelium. Science (Wash. D. C.). 197: 999-1001.

32. Bresnihan, B., and H. E. Jasin. 1977. Suppressor function of peripheral blood mononuclear cells in normal individuals and in patients with systemic lupus erythematosus. $J$. Clin. Invest. 59: 106-116.

33. Morimoto, C. 1978. Loss of suppressor T-lymphocyte function in patients with systemic lupus erythematosus (SLE). Clin. Exp. Immunol. 32: 125-133.

34. Sakane, T., A. D. Steinberg, and I. Green. 1978. Studies 
of immune functions of patients with systemic lupus erythematosus. I. Dysfunction of suppressor T-cell activity related to impaired generation of, rather than response to, suppressor cells. Arthritis Rheum. 21: 257-664.

35. Sagawa, A., and N. I. Abdou. 1978. Suppressor cell dysfunction in systemic lupus erythematosus. Cells involved and in vitro correlation. J. Clin. Invest. 62: 789-796.

36. Moretta, J., M. C. Mingari, and C. A. Romanzi. 1978. Loss of Fc receptors for IgG from human T lymphocytes exposed to IgG immune complexes. Nature (Lond.). 272: 618-620.

37. Moretta, L., M. C. Mingari, A. Moretta, and M. D. Cooper. 1979. Human T lymphocyte subpopulations. Studies of the mechanism by which $\mathrm{T}$ cells bearing $\mathrm{Fc}$ receptors for IgG suppress $\mathrm{T}$-dependent $\mathrm{B}$ cell differentiation induced by pokeweed mitogen. J. Immunol. 122: 984-990.

38. Samarut, C., and J. P. Revillard. 1979. Modulation of lymphocyte receptors for IgG inhibits responding cells in the mixed lymphocyte reaction. Transplantation (Baltimore). In press.

39. Pichler, W. J., L. Lum, and S. Broder. 1978. Fc receptors on human T lymphocytes. I. Transition of T $\gamma$ to $\mathrm{T} \mu$ cells. $J$. Immunol. 121: 1540-1548.

40. Haynes, B. F., and A. S. Fauci. 1978. Activation of human B lymphocytes. X. Heterogeneity of concanavalin Agenerated suppressor cells of the pokeweed mitogen-induced plaque-forming cell response of human peripheral blood lymphocytes. J. Immunol. 121: 559-565.

41. Hayward, A. R., L. Layward, P. M. Lydyard, L. Moretta, M. Dagg, and A. R. Lawton. 1978. Fc-receptor heterogeneity of human suppressor T cells. J. Immunol. 212: 1-5.

42. Feldmann, J. L., J. J. Becker, H. Moutsopoulos, K. Frye, M. Blackman, W. V. Epstein, and N. Talal. 1976. Antibody-dependent cell-mediated cytotoxicity in selected autoimmune diseases. J. Clin. Invest. 58: 173-179.

43. Jasin, H. E., and M. Ziff. 1975. Immunoglobulin synthesis by peripheral blood cells in systemic lupus erythematosus. Arthritis Rheum. 18: 219-228.
44. Budman, D. R., E. B. Merchant, A. D. Steinberg, B. Draft, M. E. Gershwin, E. Lizzio, and J. P. Reeves. 1977. Increased spontaneous activity of antibody forming cells in the peripheral blood of patients with active systemic lupus erythematosus. Arthritis Rheum. 20: 829-833.

45. Morimoto, C., T. Abe, M. Hara, and M. Homma. 1977. In vitro TNP-specific antibody formation by peripheral lymphócytes from patients with systemic lupus erythematosus. Scand. J. Immunol. 6: 575-579.

46. Cohen, P. L., and M. Ziff. 1977. Abnormal polyclonal B cell activation in $\mathrm{NZB} / \mathrm{NZWF}_{1}$ mice. J. Immunol. 119: 1534- 1537

47. Moutsopoulos, H. M., M. Boehm-Truitt, S. S. Kassan, and T. M. Chused. 1977. Demonstration of activation of B lymphocytes in New Zealand black mice at birth by an immunoradiometric assay for murine Ig.M.J. Immunol. 119: 1639- 1644

48. Chused, T. M., H. M. Moutsopoulos, S. O. Sharrow, C. T. Hansen, and H. C. Morse. 1978. Mechanism of autoimmune disease in New Zealand black mice. In Genetic Control of Autoimmune Disease. N. R. Rose, P. E. Bigazzi, and N. L. Warner, editors. Elsevier North Holland, New York. 177-191.

49. Talal, N., R. A. Sylvester, T. E. Daniels, J. S. Greenspan, and R. C. Williams, Jr. 1974. T and B lymphocytes in peripheral blood and tissue lesions in Sjögren's syndrome. J. Clin. Invest. 53: 180-189.

50. Moutsopoulos, H., K. H. Fye, S. Sawada, M. J. Becker, A. Goldstein, and N. Talal. 1976. In vitro effect of thymosin on T-lymphocyte rosette formation in rheumatic diseases. Clin. Exp. Immunol. 26: 563-573.

51. Fauci, A. S., and D. C. Dale. 1974. The effect of in vivo hydrocortisone on subpopulations of human lymphocytes. J. Clin. Invest. 53: 240-246.

52. Haynes, B. F., and A. S. Fauci. 1978. The differential effect of in vivo hydrocortisone on the kinetics of subpopulations of human peripheral blood T lymphocytes. J. Clin. Invest. 61: 703-707. 